\title{
POTENSI GAMBUT UNTUK PENGEMBANGAN PLTU DI KECAMATAN TELUK MERANTI, KABUPATEN PELALAWAN, PROVINSI RIAU
}

\section{THE POTENTIAL OF PEAT FOR THE DEVELOPMENT OF A STEAM POWER PLANT IN TELUK MERANTI SUBDISTRICT, PELALAWAN REGENCY, RIAU PROVINCE}

\author{
Agus Subarnas dan Eska P. Dwitama \\ Pusat Sumber Daya Mineral, Batubara dan Panas Bumi \\ agussubarnas@gmail.com
}

\begin{abstract}
ABSTRAK
Sumber daya gambut di Indonesia cukup berlimpah. Terlepas dari pertentangan dalam pemanfaatannya, gambut dapat digunakan sebagai alternatif bahan bakar Pembangkit Listrik Tenaga Uap (PLTU), karena memiliki syarat yang bisa terpenuhi dan mempunyai karakteristik yang identik dengan batubara kalori rendah. Tujuan penelitian ini adalah untuk mengetahui jumlah potensi sumber daya gambut dan estimasi suplai sebagai bahan bakar alternatif untuk PLTU. Lokasi penelitian terletak di wilayah Kecamatan Teluk Meranti, Kabupaten Pelalawan, Provinsi Riau. Ketebalan gambut di daerah ini bervariasi antara $0,7 \mathrm{~m}$ sampai dengan $8,7 \mathrm{~m}$ dan memiliki nilai kalori rata-rata $5.070 \mathrm{kal} / \mathrm{gram}$ (adb). Cadangan terkira gambut yang digunakan untuk PLTU adalah gambut yang memiliki ketebalan kurang dari tiga meter sebesar 45.238.945 ton di Kecamatan Teluk Meranti. Untuk energi listrik dengan kapasitas terpasang $100 \mathrm{MW}$, gambut pada Blok Teluk Meranti dapat menyuplai bahan bakar untuk PLTU selama \pm 114 tahun.
\end{abstract}

Kata kunci: gambut, sumber daya tereka, cadangan terkira, kalori, pembangkit listrik tenaga uap

\section{ABSTRACT}

Peat resources in Indonesia are quite abundant. Despite the conflict in the use of peat today,peat can be used as an alternative fuel for electric steam power plant, because it has conditions that can be fulfilled and has a property identical to low-calorie coal that is suitable if used for power plant. The purpose of this study is to find out the potential amount of peat resources and estimated supply as an alternative fuel for power plant. The researched location is in the Teluk Meranti Subdistrict, Pelalawan District, Riau Province. Peat thickness in the area varies from $0.7 \mathrm{~m}$ to $8.7 \mathrm{~m}$, which has an average calorific value of 5,070 cal/gram (adb). Peat probable reserves used for power plant are peat which has a thickness of $<3$ meters of 45.238.945 tons in Teluk Meranti Distric. For electricity with an installed capacity of $100 \mathrm{MW}$, the peat in the Teluk Meranti Block can supply fuel for the power plant for \pm 114 years.

Keywords: peat, inferred resources, probable reserves, calorie, power plant

\section{PENDAHULUAN}

Gambut merupakan lapisan organik di permukaan, yang terbentuk dan terakumulasi dalam lingkungan asam, jenuh air, sedikit oksigen dan nutrisi (World Energy Council, 2013). Gambut mempunyai kandungan bahan organik yang cukup tinggi dan pada umumnya terjadi dari campuran fragmen-fragmen material organik yang berasal dari tumbuhan yang telah mengalami pembusukan. Pada umumnya gambut berwarna coklat sampai coklat tuakehitaman, tergantung tingkat pembusukannya. Gambut merupakan cikal bakal batubara yang mana endapan material organik sisa tumbuhan akan melalui tahapan penggambutan sebelum menuju proses pembatubaraan berikutnya. 
Indonesia merupakan salah satu Negara dengan sumber daya gambut terbesar dunia setelah Rusia, bahkan lebih besar dari Amerika dan Negara-negara Eropa lainnya (Tabel 1). Sumber daya gambut Rusia mencapai sekitar $30 \%$ dari sumber daya gambut dunia, Indonesia 15,84\%, sedangkan Finlandia dan Kanada hanya sekitar 7,07\% (Tcvetkov, 2017).

Rusia dan Negara-negara di Eropa telah lama menggunakan gambut untuk pembangkit listrik. Lebih dari $80 \%$ ekstraksi gambut dunia dilakukan oleh Negaranegara Eropa dan kurang dari 5\% oleh Amerika dan Kanada (Apuhtin dan Plakitkina, 2011). Finlandia merupakan salah satu Negara yang memanfaatkan gambut sebagai sumber energi dengan memproduksi $25,08 \%$ dari total produksi gambut dunia (Tcvetkov, 2017). Diikuti oleh Irlandia yang memproduksi $14,05 \%$ dan Swedia $12,04 \%$. Hingga saat ini gambut di Indonesia belum dimanfaatkan sebagai sumber energi.

Berdasarkan tinjauan kualitas, gambut dapat digunakan sebagai alternatif bahan bakar pada Pembangkit Listrik Tenaga Uap (PLTU), karena memiliki syarat yang bisa dipenuhi untuk kualifikasi bahan bakar PLTU dan memiliki karakteristik yang identik dengan batubara kalori rendah, sehingga dapat dimanfaatkan untuk PLTU. Dalam Energy Strategy of Russia until 2030 disebutkan bahwa biaya untuk menghasilkan 1 ton bahan bakar dari gambut akan lebih murah daripada menggunakan gas alam (Tcvetkov, 2017). Menurut kajian Clarke and Trinnaman (2010), gambut berketebalan 2 meter dengan luas 7.500 ha dapat menghasilkan listrik sekitar $120 \mathrm{MW}$ selama 20 tahun. Saat ini, beberapa negara di antaranya Irlandia dan Finlandia sudah menggunakan gambut sebagai sumber energi, baik untuk pembangkit tenaga listrik, pemanas sentral maupun sumber energi untuk industri. Penggunaan gambut untuk energi di Finlandia memiliki porsi sekitar $7 \%$ dari total pengggunaan energi pada Tahun 2003 (Kirkinen dkk, 2007).

Terlepas dari pertentangan dalam pemanfaatan gambut yang berkembang saat ini, penyelidikan ini bertujuan untuk mengetahui jumlah potensi sumber daya gambut dan estimasi suplai sebagai bahan bakar alternatif untuk PLTU. Lokasi penelitian terletak di daerah Teluk Meranti dan sekitarnya, termasuk dalam Kecamatan Teluk Meranti, Kabupaten Pelalawan, Provinsi Riau. Lokasi penelitian terletak sebelah timur Pekanbaru dengan jarak \pm 160 km (Gambar 1).

Tabel 1. Distribusi sumber daya gambut dunia

(Institute of Peat Industry 2015, USGS 2016, Peat Resources Limited 2015, WEC 2013 dalam Tcvetkov, 2017)

\begin{tabular}{|c|c|c|c|c|c|}
\hline Country & $\begin{array}{c}\text { Total reserves } \\
\text { (billion tonnes) }^{1}\end{array}$ & $\begin{array}{l}\text { Total area of } \\
\text { peatland } \\
\text { (million ha) }\end{array}$ & $\begin{array}{c}\text { Total area of } \\
\text { peatland } \\
\text { (million ha) }\end{array}$ & $\begin{array}{l}\text { Peat extraction in } \\
2009 \text { (thousand } \\
\text { tonnes) }\end{array}$ & $\begin{array}{l}\text { Peat extraction in } \\
2014 \text { (thousand } \\
\text { tonnes) }\end{array}$ \\
\hline Russia & 175.6 & 150.0 & 139.00 & 1,287 & 1,500 \\
\hline Indonesia & 78.5 & 26.0 & 20.69 & * & * \\
\hline USA & 36.3 & 40.0 & 62.50 & * & 510 \\
\hline Canada & 35.0 & 170.0 & 111.30 & * & 1,100 \\
\hline Finland & 35.0 & 10.0 & 8.90 & 4,770 & 7,500 \\
\hline China & 27.0 & 3.5 & 5.30 & * & * \\
\hline Malaysia & 11.8 & * & 2,50 & * & * \\
\hline Sweden & 11.2 & * & 2.50 & * & * \\
\hline Germany & 7.3 & * & 1.30 & * & 3,000 \\
\hline Poland & 6.0 & * & 1.25 & * & 760 \\
\hline Ireland & 5.8 & 1.2 & 1.18 & 3,089 & 4,200 \\
\hline United Kingdom & 5.7 & * & 2.75 & 20 & * \\
\hline Belarus & * & * & 2.35 & 2,944 & 3,000 \\
\hline Other & 49.7 & 12.3 & 34.08 & 713 & 4,730 \\
\hline Total & $495.4(12.0)^{2}$ & 420 & 397.35 & 13,524 & 29,900 \\
\hline
\end{tabular}

*included in data for 'other countries' 


\section{MAKALAH ILMIAH}

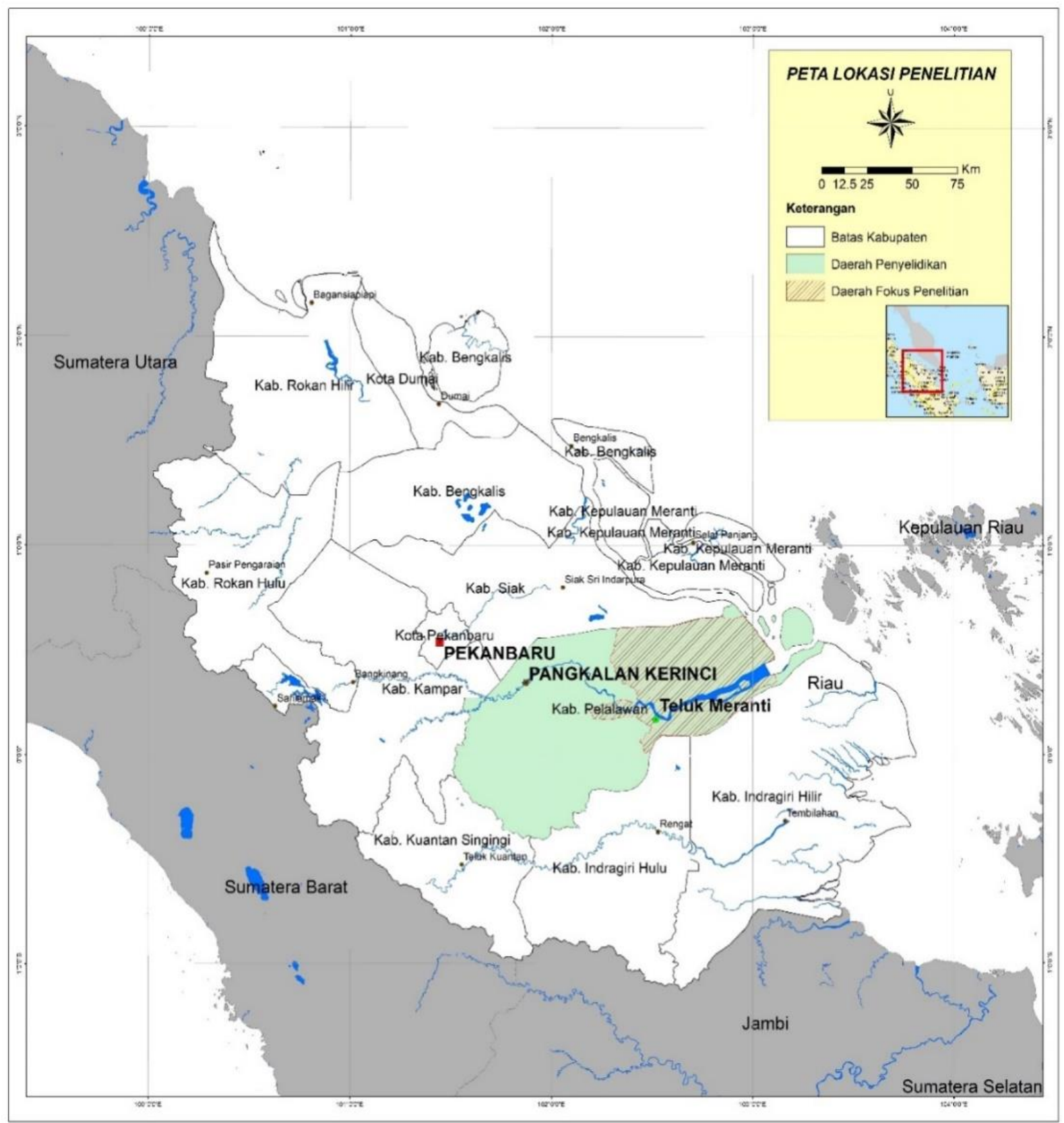

Gambar 1. Peta lokasi penelitian di daerah Teluk Meranti

\section{METODOLOGI}

Metode yang digunakan dalam penelitian ini adalah pemetaan geologi dan pengeboran dengan kedalaman maksimal 10 meter, analisis laboratorium dari percontoh gambut, dan estimasi penggunaan gambut untuk PLTU, sedangkan data yang digunakan bersumber dari hasil kegiatan Subarnas (2018).
Pemetaan geologi dilakukan untuk menentukan batas sebaran endapan gambut dan kontak endapan gambut dengan litologi lainnya. Pemetaan ini disertai dengan pengeboran menggunakan alat bor khusus gambut jenis fikelkarp auger. Penentuan lokasi titik bor ditentukan dan diusahakan memotong pusat cekungan yang telah diprediksi sebelumnya berdasarkan peta topografi dan peta geologi. Pengeboran ini 
di antaranya untuk mengetahui ketebalan endapan gambut, serta mengetahui variasi endapannya. Kegiatan analisis laboratorium dilakukan terhadap percontoh gambut hasil pemetaan dan pengeboran. Analisis yang dilakukan adalah analisis proksimat, ultimat dan nilai kalori. Beberapa parameter yang diperlihatkan dari analisis tersebut diantaranya dapat menentukan nilai kalori, karbon tertambat, kadar abu, sulfur, zat terbang, kandungan air, kelembaban, keasaman dan bulk density.

\section{GEOLOGI}

Berdasarkan Subarnas (2018), daerah penelitian termasuk dalam zona dataran rendah dengan ketinggian antara $5 \mathrm{~m}$ sampai dengan $50 \mathrm{~m}$ dari permukaan laut. Morfologinya dapat dibagi dalam dua satuan, yaitu Morfologi Dataran Rendah dan Morfologi Perbukitan Bergelombang Landai.

Morfologi Dataran Rendah terutama pada bagian tengah hingga timur daerah penelitian, ke arah timur Satuan Morfologi Dataran Rendah berkembang menjadi endapan rawa dan endapan pantai yang seluruhnya ditempati oleh endapan gambut, sedangkan ke arah barat endapan gambut sudah tidak terbentuk. Hal ini dicerminkan oleh keadaan topografinya yang makin tinggi dan menjadi Satuan Morfologi Perbukitan Bergelombang Landai.

Di daerah penyelidikan terdapat beberapa buah sungai besar, yaitu Sungai Kampar dan Sungai Selat Panjang serta anak-anak sungainya. Sungai-sungai ini membentuk beberapa cekungan yang agak memanjang dengan arah barat hingga timur yang terisi oleh endapan gambut. Hampir semua sungai-sungai ini mengalir kebagian barat.
Stratigrafi pada lahan gambut umumnya berumur Kuarter. Urutan stratigrafis di daerah survei tinjau (Clarkedkk., 1982; Camerondkk., 1982; Silitonga dan Kastowo, 1995; Suwarna dkk., 1994) adalah sebagai berikut (Tabel 2):

- Aluvium. Endapan ini berada di pinggir sungai sebagai perluasan daratan. Endapan aluvial terdiri dari material lepas batulempung dan batupasir, tersingkap disekitar Sungai Kampar dan Sungai Selat Panjang.

- Endapan tanggul (levee) terbentuk di pinggir sungai dan berfungsi sebagai tanggul alam. Endapan ini terbentuk oleh endapan sungai pada saat banjir yang membawa material-material berukuran agak kasar dan kemudian diendapkan dipinggir sungai. Pada saat permukaan air maksimum, tanggul sungai ini lebih tinggi dan menjadi pemisah antara dataran banjir dengan sungai. Endapan tanggul terdiri dari material lempung, lanau dan pasir. Endapan tanggul di daerah survei tinjau merupakan Endapan Aluvial Tua (Qap)

- Undak sungai (Qrt), terjadi akibat erosi vertikal lebih dominan dibanding erosi lateral. Di daerah penyelidikan, undak sungai terdiri dari aluvium yang membentuk morfologi pedataran. Endapan ini terdiri dari material kerikil, kerakal dan batupasir.

- Endapan organik, terbentuk pada bagian paling akhir dari dataran banjir. Pada bagian bawah, endapan organik bercampur dengan unsur anorganik, yaitu lempung dan lanau. Pada bagian atas terdapat endapan gambut yang disisipi oleh bagian tumbuhan seperti ranting, daun dan cabang yang telah membusuk yang disebut humus. Kondisi ini merupakan indikasi umum dari endapan gambut. Endapan ini di daerah penyelidikan termasuk dalam Endapan Rawa (Qs). Kenampakan endapan gambut pada daerah penelitian diperlihatkan pada Gambar 2. 


\section{MAKALAH ILMIAH}

Tabel 2. Stratigrafi daerah penyelidikan (Clarke dkk., 1982; Cameron, dkk., 1982;

Silitonga dan Kastowo, 1995; Suwarna, dkk., 1994)

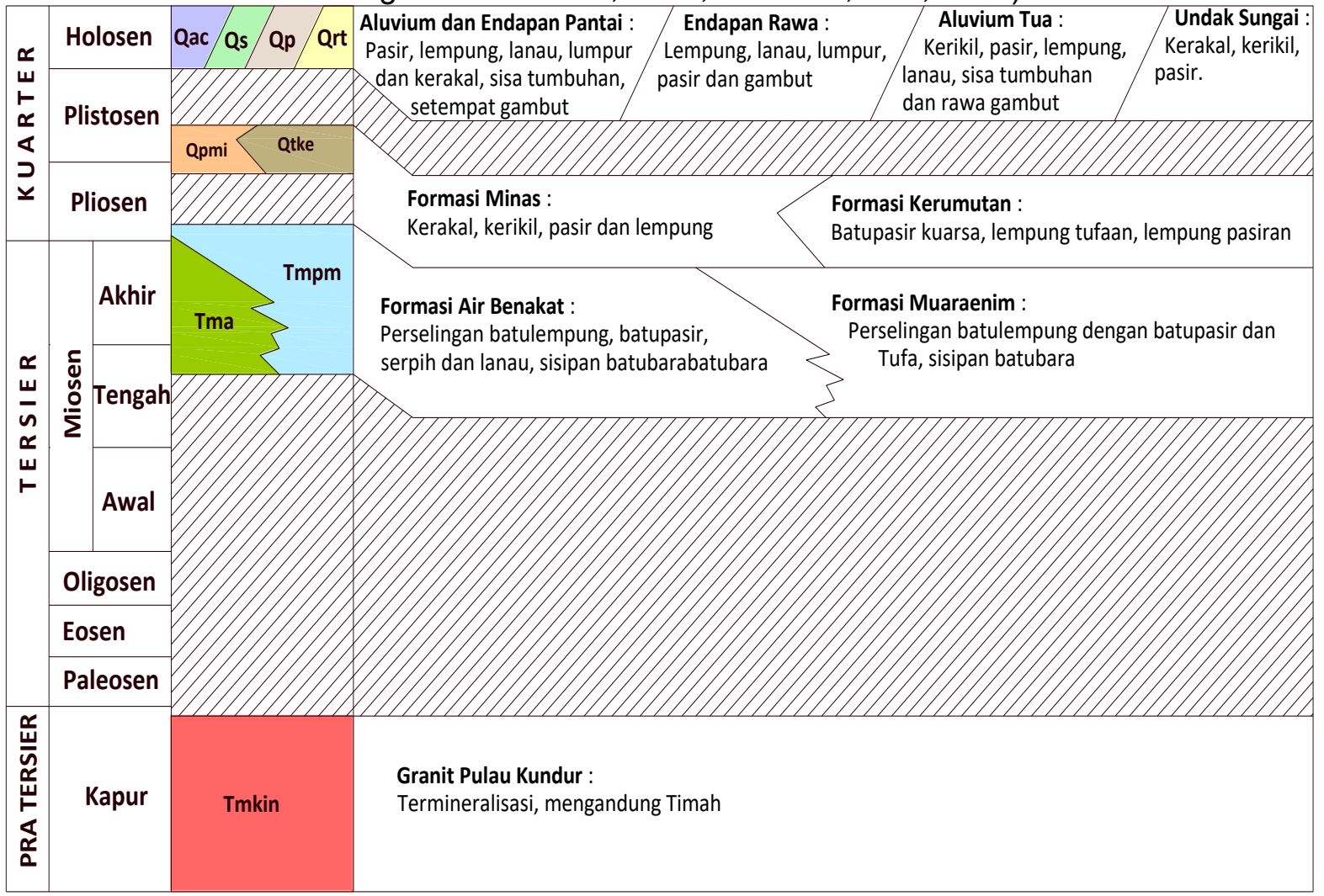

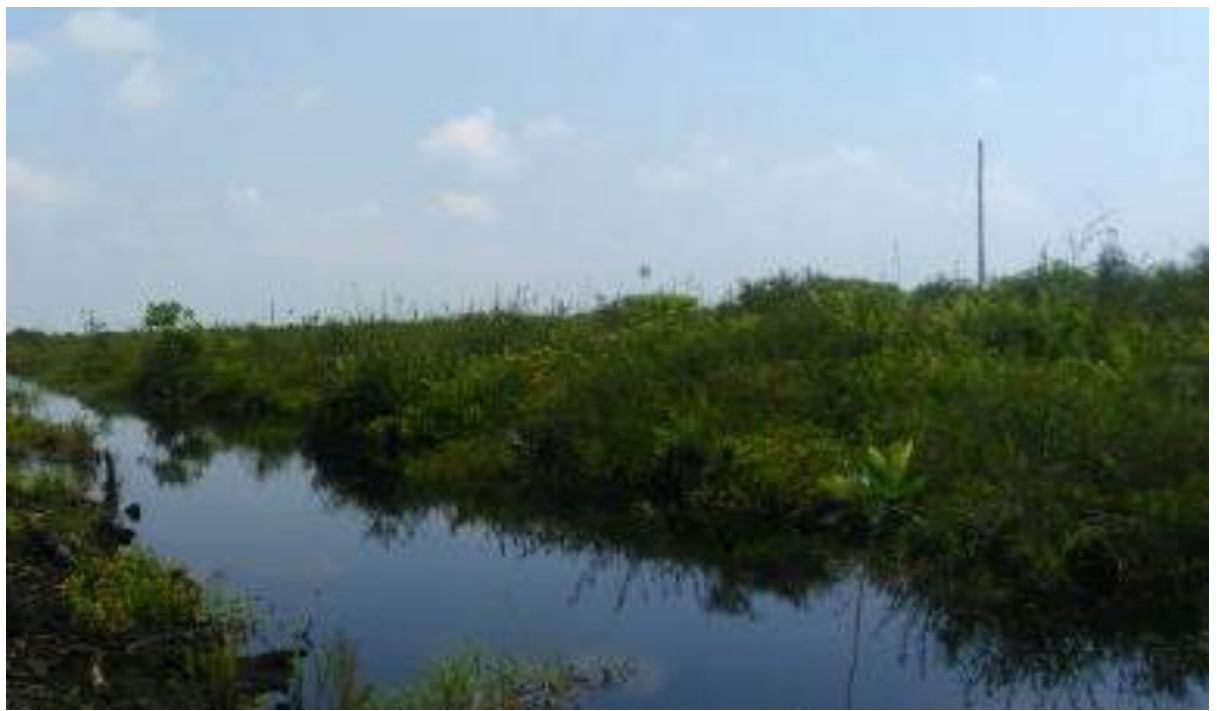

Gambar 2. Endapan gambut di daerah Teluk Meranti

Endapan dasar gambut substrat, umumnya terdiri dari lempung dengan kandungan partikel-partikel organik, berwarna abu-abu terang sampai gelap, plastis dan mengandung organik. Gambut diperkirakan berada di atas batulempung Formasi Minas dan di atas batulempung pasiran Formasi Kerumutan yang dibuktikan dengan kenampakan batas antara gambut dan batulempung hasil pengeboran (Gambar 3). Kedua formasi tersebut berumur Plio hingga Plistosen. Berdasarkan pengamatan di lapangan tidak dijumpai adanya pengaruh struktur geologi di daerah tersebut. 


\section{HASIL DAN PEMBAHASAN}

\section{Hasil}

Berdasarkan hasil pemetaan geologi didapat data sebaran gambut yang diperoleh dari 56 titik pengeboran (Tabel 3). Gambut pada cekungan ini terbentuk di antara tanggul Sungai Kampar dan sebaran serta ketebalan gambut daerah penelitian disajikan dalam Peta Sebaran dan Isopach Gambut Blok Teluk Meranti Sekala 1 : 250.000, dengan ketebalan gambut antara 0,7 m sampai dengan $8,7 \mathrm{~m}$ (Gambar 4).

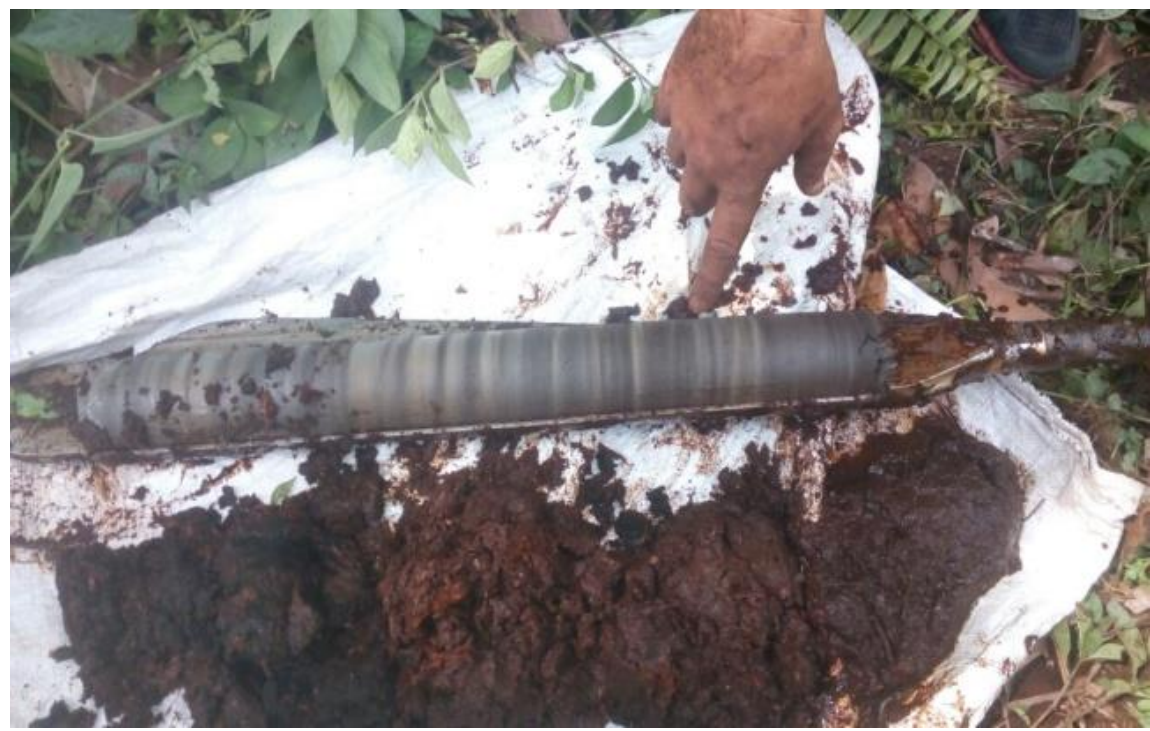

Gambar 3. Batas ketebalan gambut pada PL-46

Tabel 3. Data gambut hasil pengeboran blok Teluk Meranti

\begin{tabular}{|c|c|c|c|c|}
\hline No & $\begin{array}{c}\text { Titik } \\
\text { pengamatan }\end{array}$ & $\begin{array}{l}\text { Tebal } \\
\text { (m) }\end{array}$ & $\begin{array}{l}\text { Percontoh } \\
\text { di uji }\end{array}$ & Pemerian \\
\hline 1 & PL-07 & 0,8 & & Gambut, coklat, MAT <1 m, f, Low ash, Highly acidic, H5-H8. \\
\hline 2 & PL-08 & 0,7 & & Gambut, coklat, MAT >1 m, f, Low ash, Highly acidic, H5-H8. \\
\hline 3 & PL-09 & 4,7 & $\sqrt{ }$ & Gambut, coklat, MAT >1 m, f, Low ash, Highly acidic, H5-H8. \\
\hline 4 & $\mathrm{PL}-10$ & 8,1 & $\sqrt{ }$ & Gambut, coklat kehitaman, MAT <1 m, f-h, Low ash, Highly acidic, H5-H9. \\
\hline 5 & PL-11 & 7,6 & $\sqrt{ }$ & Gambut, coklat kehitaman, MAT 0,8 m, f, Low ash, Highly acidic, H5-H8. \\
\hline 6 & $\mathrm{PL}-12$ & 5,1 & & Gambut, coklat kehitaman, MAT 0,4 m, f-h, Low ash, Highly acidic, H5-H9. \\
\hline 7 & $\mathrm{PL}-13$ & 6,5 & $\sqrt{ }$ & Gambut, coklat kehitaman, MAT 1 m, f-h, Low ash, Highly acidic, H5-H9. \\
\hline 8 & $\mathrm{PL}-15$ & $>2$ & & Gambut, coklat kehitaman, MAT 0,8 m, f, Low ash, Highly acidic, H5-H8 \\
\hline 9 & PL-16 & 3,0 & $\sqrt{ }$ & Gambut, coklat kehitaman, MAT <1 m, f-h, Low ash, Highly acidic, H5-H9. \\
\hline 10 & PL-17 & 4,0 & & Gambut, coklat, MAT >1 m, f, Low ash, Highly acidic, H5-H8. \\
\hline 11 & PL-18 & 4,65 & $\sqrt{ }$ & Gambut, coklat, MAT >1 m, f-h, Low ash, Highly acidic, H5-H9. \\
\hline 12 & PL-19 & 6,6 & $\sqrt{ }$ & Gambut, coklat, MAT >1 m, f-h, Low ash, Highly acidic, H5-H9. \\
\hline 13 & PL-20 & $>4,2$ & & Gambut, coklat, MAT >1 m, f-h, Low ash, Highly acidic, H5-H9. \\
\hline 14 & PL-21 & 7,4 & $\sqrt{ }$ & Gambut, coklat kehitaman, MAT 0,7 m, f-h, Low ash, Highly acidic, H5-H9. \\
\hline 15 & $\mathrm{PL}-22$ & 8,4 & & Gambut, coklat kehitaman, MAT 1 m, f-h, Low ash, Highly acidic, H5-H9. \\
\hline 16 & PL-23 & 8,7 & $\sqrt{ }$ & Gambut, coklat kehitaman, MAT 1 m, f-h, Low ash, Highly acidic, H5-H9. \\
\hline 17 & PL-24 & 5,8 & $\sqrt{ }$ & Gambut, coklat kehitaman, MAT 0,5 m, f-h, Low ash, Highly acidic, H5-H9. \\
\hline 18 & PL-25 & $>5,7$ & $\sqrt{ }$ & Gambut, coklat kehitaman, MAT 1 m, f-h, Low ash, Highly acidic, H5-H9. \\
\hline 19 & PL-26 & $>5,8$ & $\sqrt{ }$ & Gambut, coklat kehitaman, MAT < 1m, h, Low ash, Highly acidic, $\mathrm{H} 7-\mathrm{H} 9$. \\
\hline 20 & PL-27 & 4,8 & $\sqrt{ }$ & Gambut, coklat kehitaman, MAT 1 m, f-h, Low ash, Highly acidic, H5-H9. \\
\hline 21 & PL-28 & 6,4 & & Gambut, coklat, MAT 0,7 m, f, Low ash, Highly acidic, H5-H8 \\
\hline 22 & PL-29 & $>4,9$ & & Gambut, coklat kehitaman, MAT 0,8 m, f, Low ash, Highly acidic, H5-H8 \\
\hline 23 & PL-30 & 6,4 & & Gambut, coklat kehitaman, MAT 1 m, f-h, Low ash, Highly acidic, H5-H9. \\
\hline 24 & PL-31 & 6,1 & & Gambut, coklat kehitaman, MAT 1 m, f-h, Low ash, Highly acidic, H5-H9. \\
\hline 25 & $\mathrm{PL}-32$ & 7,4 & & Gambut, coklat kehitaman, MAT 1 m, f-h, Low ash, Highly acidic, H5-H9. \\
\hline 26 & PL-33 & 7,5 & & Gambut, coklat kehitaman, MAT 1 m, f-h, Low ash, Highly acidic, H5-H9. \\
\hline 27 & PL-34 & 1,7 & & Gambut, coklat, MAT 1 m, f, Low ash, Highly acidic, H5-H8 \\
\hline 28 & PL-35 & 2,0 & & Gambut, coklat, MAT 1 m, f, Low ash, Highly acidic, H5-H8 \\
\hline 29 & PL-36 & 1,8 & & Gambut, coklat, MAT $1 \mathrm{~m}, \mathrm{f}$, Low ash, Highly acidic, H5-H8 \\
\hline 30 & PL-37 & 2,3 & & Gambut, coklat, MAT $1 \mathrm{~m}, \mathrm{f}$, Low ash, Highly acidic, H5-H8 \\
\hline
\end{tabular}




\section{MAKALAH ILMIAH}

\begin{tabular}{|c|c|c|c|c|}
\hline No & $\begin{array}{c}\text { Titik } \\
\text { pengamatan }\end{array}$ & $\begin{array}{l}\text { Tebal } \\
(\mathrm{m})\end{array}$ & $\begin{array}{l}\text { Percontoh } \\
\text { di uji }\end{array}$ & Pemerian \\
\hline 31 & PL-38 & 3.8 & & Gambut, coklat kehitaman, MAT 1 m, f-h, Low ash, Highly acidic, H5-H9. \\
\hline 32 & PL-39 & 1,9 & & Gambut, coklat, MAT >1 m, f, Low ash, Highly acidic, H5-H8 \\
\hline 33 & PL-40 & 2,2 & & Gambut, coklat, MAT $1 \mathrm{~m}, \mathrm{f}$, Low ash, Highly acidic, H5-H8 \\
\hline 34 & $\mathrm{PL}-41$ & 4,7 & & Gambut, coklat, MAT <1 m, f, Low ash, Highly acidic, H5-H8 \\
\hline 35 & $\mathrm{PL}-42$ & 7,8 & & Gambut, coklat, MAT <1 m, f, Low ash, Highly acidic, H5-H8 \\
\hline 36 & $\mathrm{PL}-43$ & 7,4 & & Gambut, coklat kehitaman, MAT <1 m, f-h, Low ash, Highly acidic, H5-H9. \\
\hline 37 & $\mathrm{PL}-44$ & 8,0 & & Gambut, coklat kehitaman, MAT 1 m, f-h, Low ash, Highly acidic, H5-H9. \\
\hline 38 & $\mathrm{PL}-45$ & 6,7 & & Gambut, coklat kehitaman, MAT 1 m, f-h, Low ash, Highly acidic, H5-H9. \\
\hline 39 & PL-46 & 8,1 & & Gambut, coklat kehitaman, MAT 1 m, f-h, Low ash, Highly acidic, H5-H9. \\
\hline 40 & PL-47 & 6,7 & & Gambut, coklat kehitaman, MAT 1 m, f-h, Low ash, Highly acidic, H5-H9. \\
\hline 41 & PL-48 & 6,7 & & Gambut, coklat kehitaman, MAT 0,7 m, f-h, Low ash, Highly acidic, H5-H9. \\
\hline 42 & PL-49 & 1,9 & & Gambut, coklat kehitaman, MAT >1 m, f, Low ash, Highly acidic, H5-H8 \\
\hline 43 & PL-50 & 1,4 & & Gambut, coklat, MAT 0,8 m, f, Low ash, Highly acidic, H5-H8 \\
\hline 44 & PL-51 & 4,7 & & Gambut, coklat kehitaman, MAT <1 m, f, Low ash, Highly acidic, H5-H8 \\
\hline 45 & PL-52 & 4,7 & & Gambut, coklat kehitaman, MAT <1 m, f, Low ash, Highly acidic, $\mathrm{H} 5-\mathrm{H} 8$ \\
\hline 46 & PL-53 & 7,1 & & Gambut, coklat kehitaman, MAT <1 m, $f-h$, Low ash, Highly acidic, H5-H9 \\
\hline 47 & PL-54 & 3,1 & & Gambut, coklat, MAT >1 m, f, Low ash, Highly acidic, H5-H8 \\
\hline 48 & PL-55 & 5,8 & & Gambut, coklat, MAT <1 m, f-h, Low ash, Highly acidic, H5-H9 \\
\hline 49 & PL-56 & 3,8 & & Gambut, coklat, MAT 0,8 m, f, Low ash, Highly acidic, H5-H8 \\
\hline 50 & PL-57 & 3,8 & & Gambut, coklat kehitaman, MAT 0,8 m, f, Low ash, Highly acidic, H5-H8 \\
\hline 51 & PL-59 & 4,0 & $\sqrt{ }$ & Gambut, coklat, MAT <1 m, f, Low ash, Highly acidic, H5-H8 \\
\hline 52 & PL-60 & 4,6 & & Gambut, coklat, MAT <1 m, f, Low ash, Highly acidic, H5-H8 \\
\hline 53 & PL-61 & 6,1 & & Gambut, coklat kehitaman, MAT $<1 \mathrm{~m}, \mathrm{f}-\mathrm{h}$, Low ash, Highly acidic, $H 5-\mathrm{H} 9$ \\
\hline 54 & PL-62 & 4,4 & $\sqrt{ }$ & Gambut, coklat, MAT <1 m, f, Low ash, Highly acidic, H5-H8 \\
\hline 55 & PL-63 & 7,2 & & Gambut, coklat kehitaman, MAT $<0,7 \mathrm{~m}, f$, Low ash, Highly acidic, H5-H8 \\
\hline 56 & PL-64 & 5,9 & $\sqrt{ }$ & Gambut, coklat kehitaman, MAT <0,7 m, $f$, Low ash, Highly acidic, H5-H8 \\
\hline
\end{tabular}

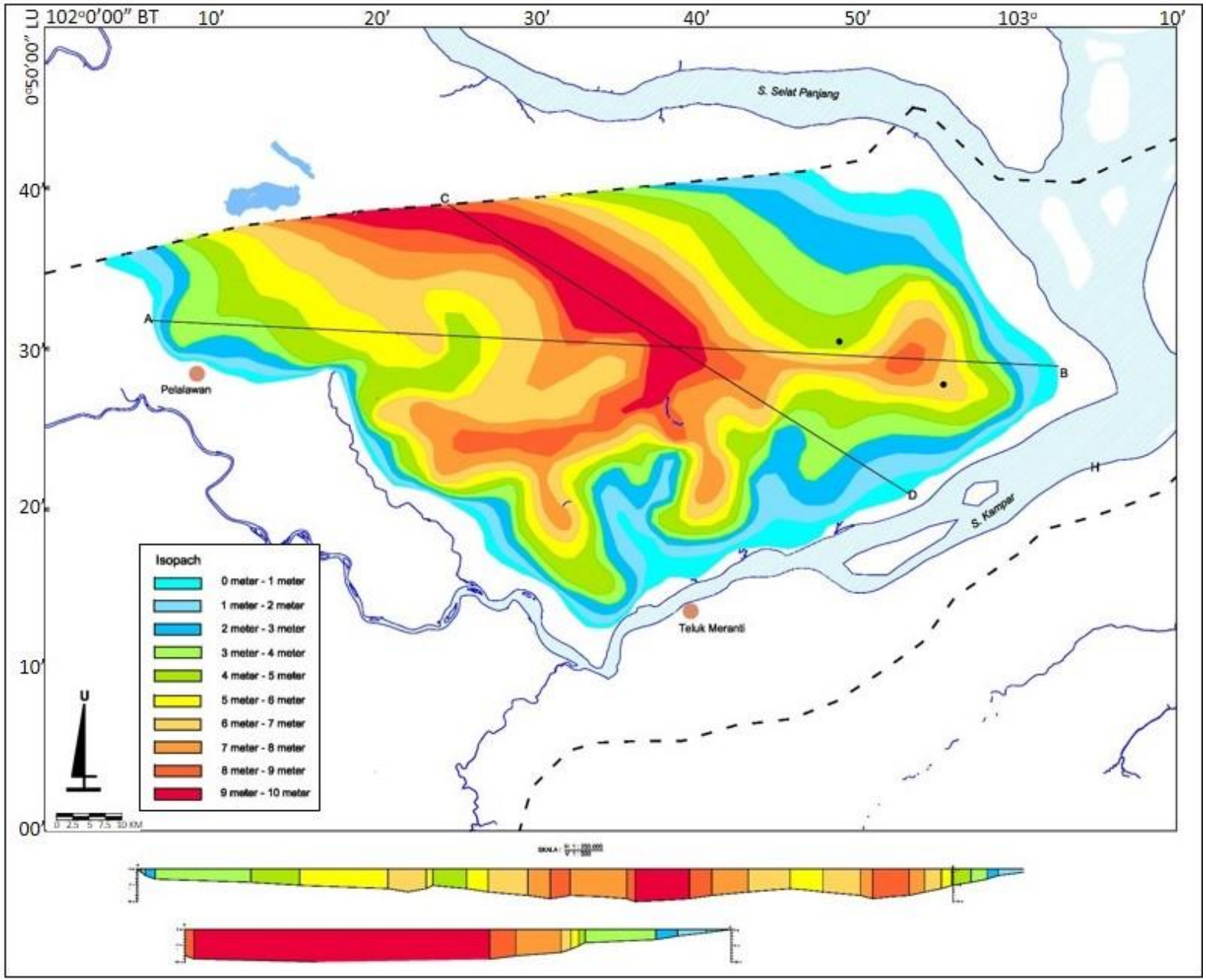

Gambar 4. Peta sebaran dan isopah gambut Blok Teluk Meranti 


\section{MAKALAH ILMIAH}

\section{Kualitas Gambut}

Kualitas gambut ditentukan oleh hasil analisis kimia berupa analisis proksimat, ultimat dan nilai kalori (Tabel 4). Gambut di daerah penelitian memperlihatkan nilai kalori rata-rata $5.079 \mathrm{kal} / \mathrm{gram}$ (adb), kandungan abu rata-rata $0,23 \%$, sulfur total rata-rata $0,20 \%$ termasuk sangat rendah, kandungan inherent moisture ratarata $9,06 \%$ dan kandungan karbon tertambat sebesar 30,46\%. Hasil analisis ultimat menunjukkan nilai karbon rata-rata $62,39 \%$, hidrogen sekitar $5,26 \%$, nitrogen $1,13 \%$, sulfur $0,23 \%$ dan oksigen $31,10 \%$.

Gambut di daerah Teluk Meranti pada umumnya juga telah mengalami dekomposisi menengah hingga tinggi antara H5 sampai H9 (Landva and Pheneey, 1980 in M. A. Rahgozar and M. Saberian, 2015). Persyaratan lain yang cukup baik dari gambut di daerah Teluk Meranti sebagai bahan bakar PLTU adalah mempunyai nilai kalori rata-rata 5.079 $\mathrm{kal} / \mathrm{gr}$ dengan kandungan abu rata-rata
$0,23 \%$ serta total sulfur sangat rendah $<1 \%$, yaitu $0,20 \%$.

\section{Sumber Daya Gambut Blok Teluk Meranti}

Secara administratif, Blok Gambut Teluk Meranti terletak di Kecamatan Teluk Meranti yang terdiri dari beberapa desa, di antaranya Pulau Muda, Gambut Mutiara dan Segamai. Sebaran gambut pada blok ini seluruhnya berada pada hutan produksi pada sistem Tata Guna Lahan Kabupaten Pelalawan dan saat ini sebagian besar lahan gambut di daerah ini telah berubah fungsi menjadi areal hutan tanam industri dari beberapa perusahaan swasta dan tidak ada permukiman masyarakat di daerah ini.

Luas sebaran gambut di daerah Teluk Meranti yang terpetakan pada kegiatan penyelidikan ini seluas $331.885,74$ ha sampai isopah dengan tebal 10 meter, bahwa total sumber daya tereka gambut sebesar 327.619 .732 ton gambut kering (Tabel 5).

Tabel 4. Data kualitas gambut Blok Teluk Meranti

\begin{tabular}{|c|c|c|c|c|}
\hline Parameter & Unit & Basis & Kisaran & Rata-rata \\
\hline Lembab Nisbi & $\%$ & ar & $82,90-91,77$ & 89,17 \\
\hline Lembab Jumlah & $\%$ & ar & $84,45-92,66$ & 90,15 \\
\hline \multicolumn{5}{|l|}{ Proksimat } \\
\hline Kadar air & $\%$ & $a d b$ & $8,40-10,34$ & 9,06 \\
\hline Zat Terbang & $\%$ & $a d b$ & $54,67-60,17$ & 57,95 \\
\hline Karbon Tertambat & $\%$ & $a d b$ & $27,40-32,45$ & 30,46 \\
\hline $\mathrm{Abu}$ & $\%$ & $a d b$ & $0,64-6,37$ & 2,39 \\
\hline Sulfur total & $\%$ & $a d b$ & $0,11-0,40$ & 0,20 \\
\hline Berat Jenis & $\%$ & $a d b$ & $0,08-0,13$ & 0,10 \\
\hline $\mathrm{PH}$ & & & $3,51-5,16$ & 4,12 \\
\hline Nilai Kalori & $\mathrm{Kal} / \mathrm{gr}$ & $a d b$ & $4.895-5.389$ & 5.079 \\
\hline \multicolumn{5}{|l|}{ Ultimat } \\
\hline Karbon & $\%$ & daf & $61,34-64,35$ & 62,39 \\
\hline Hidrogen & $\%$ & daf & $5,01-5,48$ & 5,26 \\
\hline Oksigen & $\%$ & daf & $28,99-32,08$ & 31,10 \\
\hline Nitrogen & $\%$ & daf & $0,92-1,42$ & 1,13 \\
\hline Sulfur & $\%$ & daf & $0,12-0,45$ & 0,23 \\
\hline
\end{tabular}

Tabel 5. Sumber Daya Tereka Gambut Blok Teluk Meranti

\begin{tabular}{|c|c|c|c|c|}
\hline \multirow{2}{*}{$\begin{array}{l}\text { Zona Ketebalan } \\
(\mathrm{m})\end{array}$} & \multicolumn{4}{|c|}{ Blok Teluk Meranti } \\
\hline & Luas $\left(\mathrm{m}^{2}\right)$ & Tebal (m) & Bulk Density (ton/m²) & Sumber Daya (ton) \\
\hline $0-1$ & $228.339 .025,68$ & 1,0 & 0,10 & 22.833 .902 \\
\hline $1-2$ & $282.313 .658,51$ & 1,0 & 0,10 & 28.231 .365 \\
\hline $2-3$ & $303.174 .026,13$ & 1,0 & 0,13 & 39.412 .623 \\
\hline $3-4$ & $374.747 .840,58$ & 1,0 & 0,08 & 29.979 .827 \\
\hline $4-5$ & $431.477 .126,86$ & 1,0 & 0,10 & 43.147 .712 \\
\hline $5-6$ & $406.226 .102,99$ & 1,0 & 0,10 & 40.622 .610 \\
\hline $6-7$ & $470.572 .738,08$ & 1,0 & 0,10 & 47.057 .273 \\
\hline $7-8$ & $394.268 .453,13$ & 1,0 & 0,09 & 35.484 .160 \\
\hline
\end{tabular}




\begin{tabular}{|c|c|c|c|c|}
\hline \multirow{2}{*}{$\begin{array}{l}\text { Zona Ketebalan } \\
(\mathrm{m})\end{array}$} & \multicolumn{4}{|c|}{ Blok Teluk Meranti } \\
\hline & Luas $\left(\mathrm{m}^{2}\right)$ & Tebal (m) & Bulk Density (ton $/ \mathrm{m}^{2}$ ) & Sumber Daya (ton) \\
\hline $8-9$ & $212.357 .765,59$ & 1,0 & 0,09 & 19.112 .198 \\
\hline $9-10$ & $217.380 .627,38$ & 1,0 & 0,10 & 21.738 .062 \\
\hline \multicolumn{4}{|c|}{ Total } & 327.619 .732 \\
\hline
\end{tabular}

\section{Pembahasan}

Gambut telah banyak digunakan oleh negara-negara Eropa, Amerika, dan Kanada sebagai bahan bakar untuk pembangkit listrik. Seperti contohnya di Irlandia yang memiliki tiga pembangkit listrik yang menggunakan gambut sebagai bahan bakarnya, yang tertua adalah Edenderry Power Ltd dibuka Tahun 2000 memiliki kapasitas 120 MW dan menghabiskan 1 juta ton gambut/tahun (Mahoney dan Denny, 2010).

Gambut di Finlandia yang juga dimanfaatkan untuk PLTU memiliki karakteristik moisture 30\% sampai dengan $60 \%$, kadar abu $2 \%$ sampai dengan $10 \%$, nilai kalori rata-ratanya $20 \mathrm{MJ} / \mathrm{Kg}(4.776$ $\mathrm{Kal} / \mathrm{gr}$ ) (Lehtomäki, dkk, 1981).

\section{Kajian gambut untuk PLTU}

Pada kajian bahan bakar untuk PLTU terdapat beberapa faktor pembangkitan yang harus diperhitungkan, antara lain beban, ketersediaan, penggunaan, kapasitas, pelayanan dan gangguan keluar perawatan (Marsudi, 2005; Prasetyo, dkk., 2011). Dalam tulisan ini hanya dibahas dua faktor, yaitu beban dan kapasitas serta diperhitungkan efisiensi termal dari gambut.

\section{Faktor beban}

Faktor beban adalah perbandingan antara besarnya beban rata-rata untuk selang waktu tertentu terhadap beban puncak tertinggi dalam selang waktu yang sama (misalnya satu hari atau satu bulan). Sementara beban rata-rata untuk suatu selang waktu tertentu adalah jumlah produksi $\mathrm{KWH}$ dalam selang waktu tersebut dibagi dengan jumlah jam dari selang waktu tersebut.

\section{Faktor beban = beban rata-rata/beban puncak}

Standar PLN, faktor beban tahunan berkisar antara $60 \%$ sampai dengan $80 \%$ (Marsudi, 2005 dalam Prasetyo, dkk., 2011).

\section{Faktor kapasitas}

Faktor kapasitas sebuah unit pembangkit menggambarkan seberapa besar sebuah unit pembangkit itu dimanfaatkan. Faktor kapasitas tahunan didefinisikan sebagai:

Faktor kapasitas $=$ produksi $\mathrm{KWH}$ setahun/(daya terpasang MW x 8.760 jam)

Dalam pelaksanaanya, faktor kapasitas tahunan untuk unit PLTU hanya dapat mencapai angka antara $60 \%$ sampai dengan $80 \%$, karena adanya masa pemeliharaan dan jika adanya gangguan atau kerusakan yang dialami oleh unit pembangkit tersebut (Marsudi, 2005 dalam Prasetyo, dkk., 2011).

\section{Efisiensi termal}

Menurut Moran dkk. (2014), dalam termodinamika, efisiensi termal adalah ukuran tanpa dimensi yang menunjukkan performa peralatan termal seperti mesin pembakaran dalam dan sebagainya. Panas yang masuk adalah energi yang didapatkan dari sumber energi. Output yang diinginkan dapat berupa panas atau kerja, atau mungkin keduanya. Jadi, efisiensi termal dapat dirumuskan dengan:

$$
\eta_{t h} \equiv \frac{\text { Berapa yang didapatkan }}{\text { Berapa yang dimasukan }}
$$

Berdasarkan hukum pertama termodinamika, output tidak bisa melebihi input, sehingga: 


$$
0 \leq \eta_{t h} \leq 1
$$

Efisiensi termal antara 0\% sampai dengan $100 \%$. Karena adanya inefisiensi seperti gesekan, hilangnya panas, dan faktor lainnya, efisiensi termal mesin tidak pernah mencapai $100 \%$. Seperti contoh, mesin mobil bensin memiliki efisiensi $25 \%$, dan mesin pembangkit listrik tenaga batubara yang besar memiliki efisiensi maksimum $46 \%$. Mesin diesel terbesar di dunia memiliki efisiensi maksimum 51,7\%.

Efisiensi termal PLTU di lapangan lebih kecil daripada hasil perhitungan dengan siklus kombinasi secara teoritis, karena analisis tersebut tidak memperhitungkan berbagai alat tambahan yang digunakan dalam PLTU. Berikut merupakan contoh efisiensi termal PLTU batubara berdasarkan nilai kalorinya, seperti tertera pada Tabel 6 berikut ini.

Tabel 6. Efisiensi Termal PLTU Batubara (Sinambela, 2007)

\begin{tabular}{cc}
\hline Nilai Kalori (kkal/kg) & Efisiensi Termal (\%) \\
\hline $\mathbf{4 . 0 0 0}$ & 29,60 \\
\hline $\mathbf{4 . 4 0 0}$ & 32,57 \\
\hline $\mathbf{5 . 3 0 0}$ & 39,23
\end{tabular}

\section{Estimasi penggunaan gambut untuk PLTU di Blok Teluk Meranti}

Berdasarkan Peraturan Pemerintah Nomor 57 Tahun 2016 tentang Perlindungan dan Pengelolaan Ekosistem Gambut menyatakan bahwa gambut yang memiliki ketebalan lebih dari tiga meter memiliki fungsi lindung. Merujuk hal tersebut maka gambut yang akan digunakan untuk PLTU pada blok Teluk Meranti adalah yang memiliki ketebalan kurang dari tiga meter. Total sumber daya tereka gambut di daerah tersebut sampai dengan isopah tebal $10 \mathrm{~m}$ adalah sebesar 327.619.732 ton. Sedangkan total sumber daya tereka gambut yang dapat digunakan karena memiliki ketebalan kurang dari 3 meter adalah sebesar 90.477 .890 ton (Gambar 5).

\section{Menghitung jumlah kebutuhan gambut untuk PLTU :}

\section{Konversi nilai kalori ke KWH}

Pada acuan batubara $7.000 \mathrm{kkal} / \mathrm{kg}, 1$ $\mathrm{KWH}=0,123 \mathrm{~kg}$ batubara_(Zhong, 2018). Dalam makalah ini acuan tersebut dipakai untuk gambut. Nilai kalori gambut Blok Teluk Meranti: 5.079 kal/gram (adb).

$$
\begin{aligned}
& =7.000 / 5.079 \times 0,123 \mathrm{~kg} \text { coal } \\
& \text { equivalent }=0,1695 \mathrm{~kg} \text { peat } \\
& \text { equivalent }
\end{aligned}
$$

Jadi $1 \mathrm{KWH}$ gambut $5.079 \mathrm{kkal} / \mathrm{kg}=0,1695$ $\mathrm{kg}$ peat equivalent atau $1 \mathrm{~kg}=5,899 \mathrm{KWH}$

\section{Efisiensi PLTU $30 \%$}

$1 \mathrm{~kg}$ gambut nilai kalori $5.079=30 \% \mathrm{x}$ $5,899 \mathrm{KWH}=1,7697 \mathrm{KWH}$ atau $1 \mathrm{KWH}=$ $0,5650 \mathrm{~kg}$.

Untuk PLTU kapasitas $100 \mathrm{MW}$, gambut yang dibutuhkan adalah $100.000 \times 0,5650$ $\mathrm{kg}=56.500 \mathrm{~kg} / \mathrm{jam}$.

\section{Faktor Beban $\mathbf{8 0 \%}$}

Kebutuhan 1 tahun $=56.500 \mathrm{~kg} / \mathrm{jam} \times 24$ jam $\times 365$ hari $=494.940 .000 \mathrm{~kg} /$ tahun, yang dikalikan faktor beban $80 \%$ menjadi $395.952 .000 \mathrm{~kg} / \mathrm{tahun}$ atau 395.952 ton/tahun.

Dengan asumsi bahwa dari total sumber daya tereka gambut yang ada diperkirakan hanya $50 \%$ sebagai factor pengubah yang dapat digunakan secara efektif atau sebagai cadangan terkira gambut di Teluk Meranti, maka total gambut yang kemungkinan dapat digunakan sebesar 45.238.945 ton (90.477.890 ton x 50\%). Dengan total ketersediaan gambut yang dapat dimanfaatkan sejumlah tersebut maka dapat memenuhi kebutuhan PLTU kapasitas $100 \mathrm{MW}$ selama \pm 114 tahun (45.238.945 ton/395.952 ton/tahun). 


\section{MAKALAH ILMIAH}

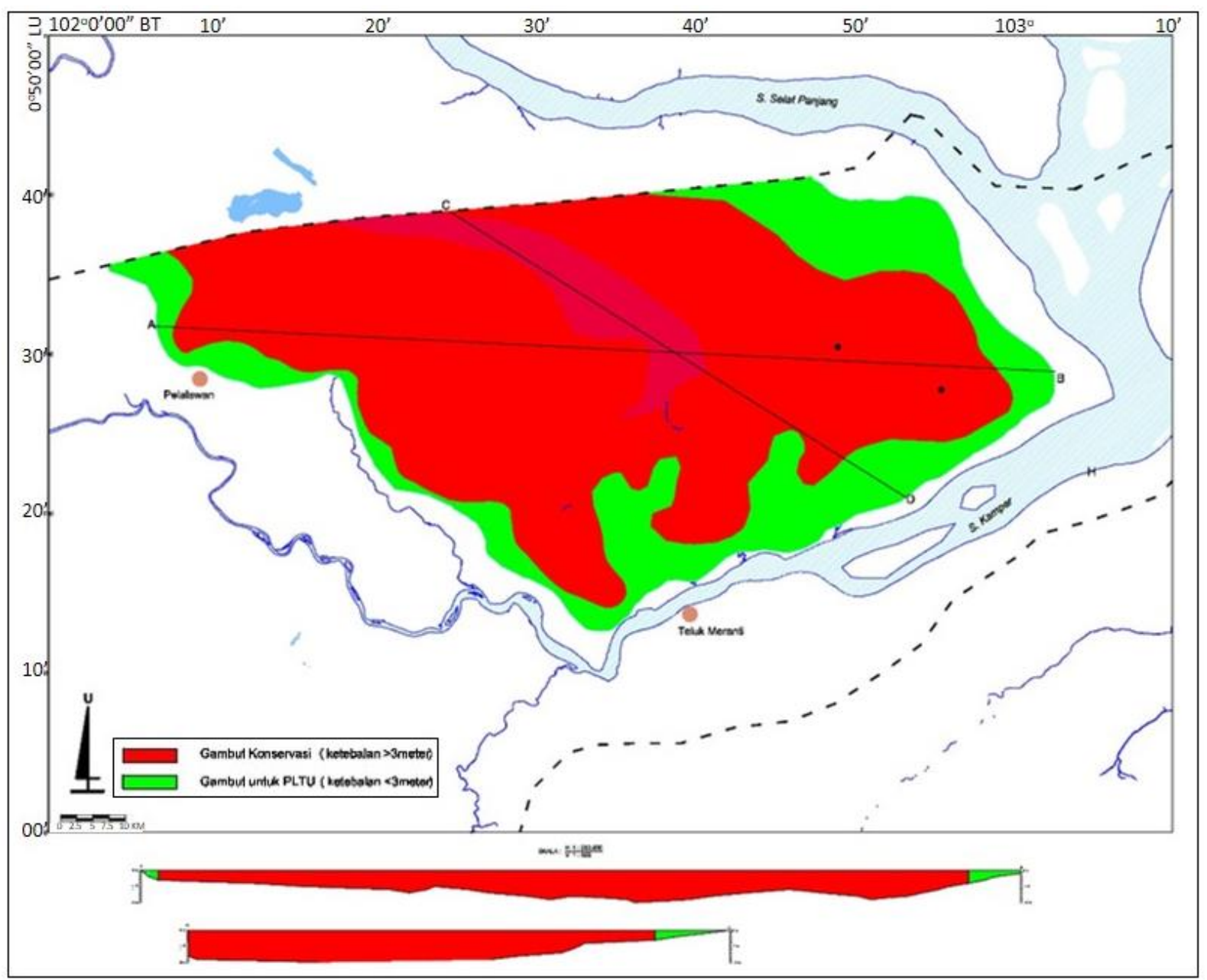

Gambar 5. Peta sebaran penggunaan lahan gambut

\section{KESIMPULAN}

Dengan memanfaatkan cadangan gambut yang memiliki ketebalan kurang dari tiga meter sebesar 45.238.945 ton pada sebaran gambut seluas di Kecamatan Teluk Meranti untuk energi listrik dengan kapasitas terpasang $100 \mathrm{MW}$, gambut pada Blok Teluk Meranti dapat menyuplai bahan bakar untuk PLTU selama \pm 114 tahun.

\section{SARAN}

Penelitian ini hanya berbasis pada satu aspek kegiatan, yaitu sumber daya gambut. Untuk melengkapi kelayakan pengembangan gambut ini, kajian keekonomian dan lingkungan (teknis dan non teknis) sangat diperlukan untuk rencana pembangunan PLTU pada masa mendatang.

\section{UCAPAN TERIMA KASIH}

Penulis mengucapkan banyak terima kasih kepada Tim Editor yang telah banyak membantu dalam penyempurnaan makalah dan kepada Dewan Redaksi atas dimuatnya makalah dalam buletin ilmiah ini.

\section{DAFTAR PUSTAKA}

Apuhtin, P. A dan Plakitkina, L. S., 2011, Peat Extraction in Russia and in the World: The Analysis of Russian and World Peat Industry Development in 2000 - 2009. Mining Industry Journal.

BPS Pelalawan, 2018, Teluk Meranti Dalam Angka 2018. Pelalawan.

Cameron, N.R., Ghazali, S.A., Thompson, S.J., 1982, Peta Geologi Lembar Siaksriindrapura dan Tanjung Pinang, Sumatera. Bandung. 


\section{MAKALAH ILMIAH}

Clarke, M.C.G., Kartawa, W., Djunuddin, A., Suganda, E., Bagdja, M., 1982, Peta Geologi Lembar Pakanbaru, Sumatera. Bandung.

Clarke, A.W., Trinnaman, J.A. (Eds.), 2010, Survey of Energy Resources. World Energy Council.

Lehtomaki ,K. J., Kortela , U. K. J.danLuukkanen ,J. J., 1981, New Estimation And Control Methods For Fuel Power In Peat Power Plants, $\left(8^{\text {th }}\right.$ Triennial World Congress) Kyoto, Japan.

Marsudi, I.D., 2005, Pembangkitan Energi Listrik. Penerbit Erlangga, Jakarta.

Moran, M.J., Shapiro, H.N., Boettner, D.D., Bailey, M.B., 2014, Fundamentals of Engineering Thermodynamics, Eight Edit. ed. Wiley, New Jersey.

Peraturan Pemerintah Nomor 57 Tahun 2016

Prasetyo, E.G., Sulasno, Handoko, S., 2011, Studi Tentang Indeks Keandalan Pembangkit Tenaga Listrik. Univ. Diponegoro.

Rahgozar, M. A. and Saberian, M., 2015, Physical and Chemical Properties of two Iranian of Type, Mires and Peat, Volume 16, Article 07, 1-17.

Silitonga, P.H., K., 1995, Peta Geologi Lembar Solok, Sumatera. Bandung.
Sinambela, Y.T., 2007, Studi Operasional PLTU Embalut dan Pengaruhnya Terhadap Tarif Listrik Regional Kalimantan Timur. Stud. Oper. PLTU Embalut dan Pengaruhnya Terhadap Tarif List. Reg. Kalimantan Timur.

Subarnas, A., 2018, Survei Tinjau Gambut, Kabupaten Pelalawan, Provinsi Riau, Pusat Sumber Daya Mineral Batubara dan Panas Bumi. Bandung. Suwarna, N., Budhitrisna, T., Santosa, S., Andi Manga, S., 1994, Peta Geologi Lembar Rengat, Sumatera. Bandung.

Tcvetkov, P.S., 2017, The history, present status and future prospects of the Russian fuel peat industry, Mires and Peat, Volume 19, International Mire Conservation Group and International Peatland Society, DOI: 10.19189/MaP.2016.OMB.256

World Energy Council (WEC), 2013, World Energy Resources: 2013 survey. World Energy Counc. 11. https://doi.org/http://www.worldenerg y.org/wpcontent/uploads/2013/09/Co mplete_WER_2013_Survey.pdf

Zhong, J., 2018. Power System Economic and Market Operations. CRC Press, Taylor and Francis Group, Boca Raton, Florida.

\begin{tabular}{ll}
\hline Diterima & $: 26$ Maret 2019 \\
Direvisi & $: 23$ Mei 2019 \\
Disetujui & $: 30$ November 2019
\end{tabular}

